\title{
Coastal Vulnerability Index for Kuwaiti Coast
}

\author{
S. Neelamani*, Dana Al-Houti, Alanoud Al-Ragum, Abeer Hassan Al-Saleh and \\ K. Al-Salem
}

Kuwait Institute for Scientific Research, PO Box: 24885, Safat 13109, Kuwait.

* Corresponding Author: nsubram@kisr.edu.kw

Submitted :01/09/2020

Revised :22/08/2021

Accepted :05/09/2021

\begin{abstract}
Kuwait is investing significantly in the development of coastal infrastructures in many of its coastal areas. It is essential to know the vulnerability of the coast of Kuwait for the future sea level rise and other physically influencing parameters. For this purpose, a detailed study is carried out and the Coastal Vulnerability Index (CVI) is established for the Kuwaiti coast including the coasts of Islands. The CVI is assessed based on the data on coastal geomorphology, historical shoreline change rate, landward side of the coastal slope, mean significant wave height, mean tidal range, and the particle size of the sediments along the beach. The total Kuwaiti coastline of $499 \mathrm{~km}$ is divided into two groups with a total of 162 coastal segments. Group 1 contains 138 segments and covers the mainland, Boubyan, and Failaka Island. Group 2 contains 24 locations and covers Umm Al-Maradim, Qaru, and Kubbar Islands. Field data collection is carried out for all these segments. From this study, it is found that $5 \%$ of the Kuwaiti coastal area in group 1 are very low vulnerable; 34\% low vulnerable; $31 \%$ moderately vulnerable; $18 \%$ highly vulnerable; and $12 \%$ are very highly vulnerable. Similar results are obtained for group 2 coastal segments. The results of this study will be useful while preparing the Integrated Coastal Zone Management plan for Kuwaiti coast and for its sustainable coastal infrastructure development.
\end{abstract}

Keywords: Kuwaiti coast; Coastal vulnerability; Resilience; Coastal infrastructure; Waves; Tides; Sea level rise; Climate change.

\section{INTRODUCTION}

Kuwait is a coastal country with a total of $499 \mathrm{~km}$ of natural coast. It is located in the northwestern part of the Arabian Gulf and is surrounded by Iraq and Saudi Arabia (Fig. 1). Coastal area is required for many socioeconomic development activities such as ports, harbors, power and desalination plants, marinas, water sports, hotels, tourism developments, and entertainment activities. The coast area is delicate and reacts quickly (both positively and negatively) during infrastructure developments. Any developmental activity increases the environmental stress level in this area. Added to this, the global climate is changing; average temperature of the atmosphere is increasing; the melting rates of polar ice sheets are increasing; and hence the sea level is rising. This is expected to result in accelerated submergence of coastal areas in future. The sea level rise may also result in more ferocious wave action on the coast and increase the rate of coastal erosion. 


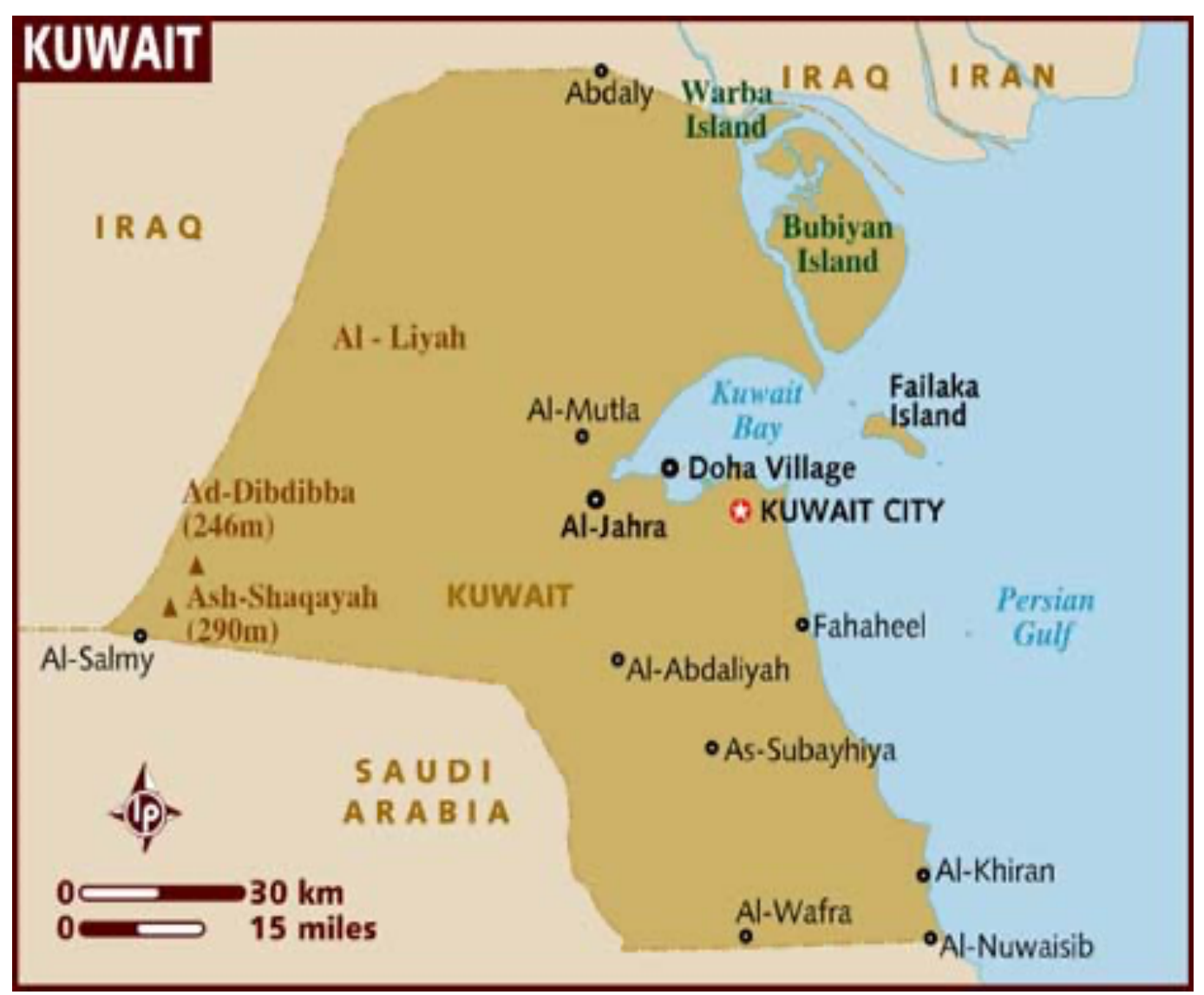

Figure 1. Kuwait and its boundaries.

The prediction of the future sea level rise is also uncertain (Dow and Downing, 2011). If the worldwide greenhouse gas emission is controlled significantly, the rate of sea level rise may reduce to $0.3 \mathrm{~m}$ by 2100 (IPCC 2014). In many countries around the world, due to coastal zone regulations, some width of the coastal land from high water line (set back distance) is not allowed for any construction activity and is the buffer for the sea to advance into the beach due to sea level increase. For example, the setback distance varies from $20 \mathrm{~m}$ to $80 \mathrm{~m}$ for Latin America and Caribbean countries (Simpson et al., 2012), 6 to $61 \mathrm{~m}$ in USA (Cheong, 2008), and up to $100 \mathrm{~m}$ for many European countries (Sanò et al., 2011). The coastal Wiki (http://www.coastalwiki.org/ wiki/Setback_area) provides the setback distance for different countries. For example, the setback distance followed in Germany is from 100 to 200 m; in India, it is from 200 to 500 m; and, in Australia (New South Wales), it is $1000 \mathrm{~m}$. As on date, such regulation is not imposed in Kuwait. Significant stretch of the coastal areas near the high water line in Kuwait is already occupied by beach houses, hotels, and many other infrastructures as shown in the sample in Fig. 2. 


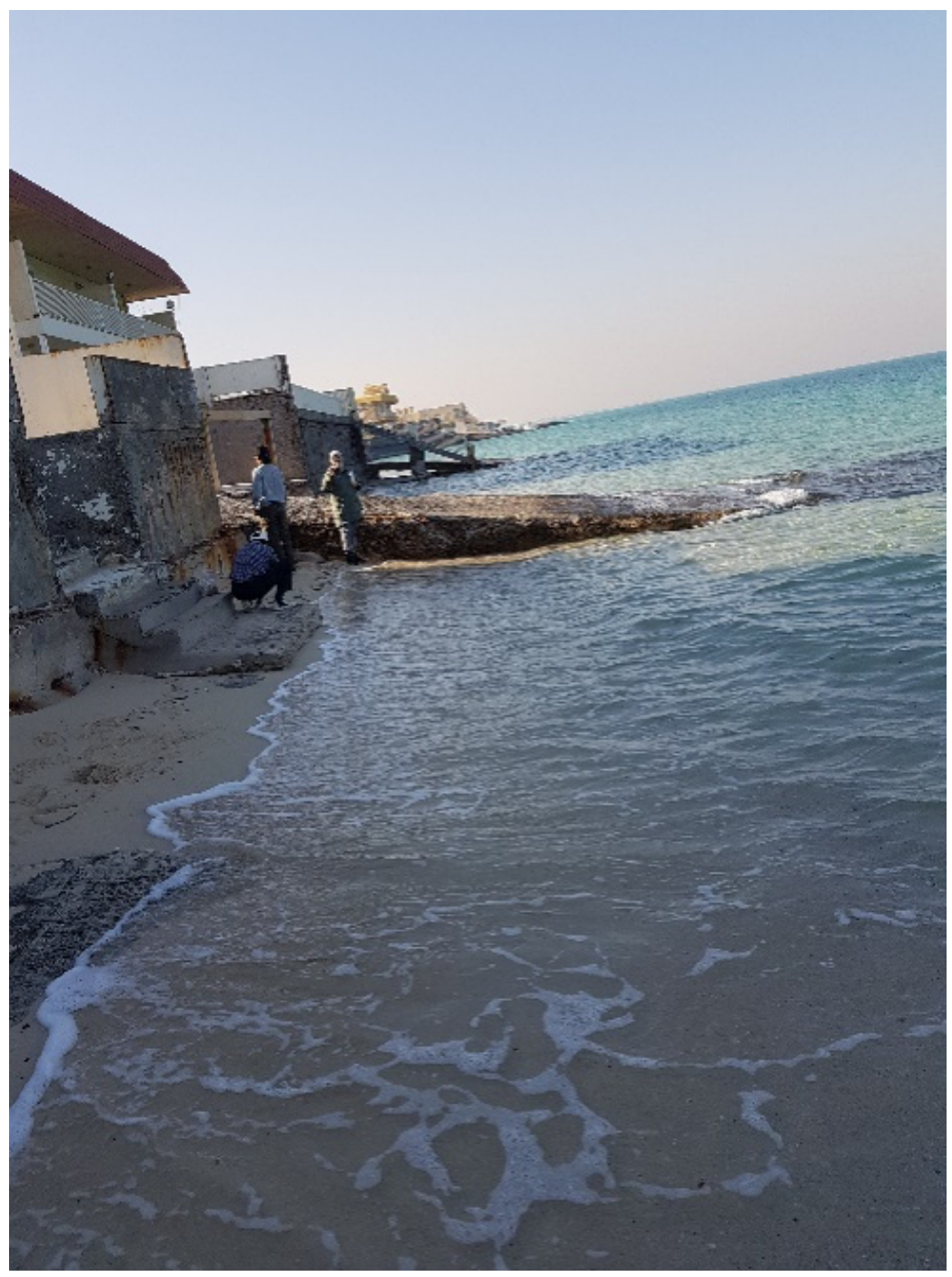

Figure 2. Beach houses near shoreline in Bnaider, Kuwait, at latitude $28^{\circ} 45^{\prime} 14.36^{\prime \prime}$ and longitude $48^{\circ} 19^{\prime}$ 54.73" captured on 5 Dec 2017.

An increase in sea level could increase the shoreline erosion (Dronkers et al., 1990). It will exacerbate coastal flooding; inundate coastal wetlands, and low-lying lands. It also increases the salinity of coastal aquifers; changes the tidal ranges; and drowns the coral reefs and other coastal infrastructures. Hence, a better understanding of vulnerability of Kuwaiti coast is important for future sustainable coastal development. One way for overall understanding of the coastal vulnerability of the Kuwaiti coast is based on an index called Coastal Vulnerability Index (CVI), by suitably considering the coastal geomorphology, relative sea level rise, historical shoreline change rate, landward coastal slope, wave height, tidal variation, and particle size of the beach soil at different coastal segments. If a scientifically assessed CVI is available for Kuwait, then it will be useful for the Kuwaiti government and decision makers to plan and take necessary action. In addition to integrated and sustainable coastal zone management of Kuwaiti coast, this type of study is also needed for the decision makers for the preparation of adaptation and resilience strategies. 


\section{LITERATURE REVIEW}

Many coastal countries around the world have carried out coastal vulnerability analysis of their coast due to future sea level rise. Researchers use either index based methods or indicator based methods or GIS based decision support system or methods based on dynamic numerical models to understand coastal vulnerability in future.

Some interesting studies from different countries around the world are Gornitz and Kanciruk, 1989, Gornitz, 1991, Gornitz et al., 1991, and Diez et al., 2007 for USA; Shaw et al., 1998 for Canada; Doukakis, 2005 for Greece; Coelho et al., 2006 for west coast of Portugal; Yin et al., 2012 for China; Kumar et al., 2010 for India; Ozyurt and Ergin, 2010 for Turkey; Duriyapong and Nakhapakorn, 2011 for Thailand; Addo, 2013 for Ghana; Zanetti et al., 2016 for Brazil; Wahab, 2017 for Malaysia; Tano et al., 2018 for Ivorian coast, west Africa; Kantamaneni et al., 2018 for some cities in UK; and so on. Not many detailed studies were carried out on coastal vulnerability of the Arab coastal region. Dasgupta et al., 2007 have carried out a comparative analysis of the impact of sea level rise on developing countries. They found that sea level rise (SLR) due to climate change is a serious global threat and the available scientific evidence is overwhelming. Continued growth of greenhouse gas emissions and associated global warming may result in SLR of $1 \mathrm{~m}$ to $3 \mathrm{~m}$ in this century.

Unexpectedly, rapid breakup of the Greenland and West Antarctic ice sheets might produce a 5m SLR. The authors have assessed the consequences of continued SLR for 84 developing countries. Geographic Information System (GIS) software was used to overlay the best available, spatially disaggregated global data on critical impact elements such as land, population, agriculture, urban extent, wetlands, and GDP with the inundation zones projected for 1 to $5 \mathrm{~m}$ SLR. The study results reveal that hundreds of millions of people in the developing world are likely to be displaced by SLR within this century; and the accompanying economic and ecological damage will be severe for many. At the country level, results are extremely skewed, with severe impacts limited to a relatively small number of countries. For these countries (e.g., Vietnam, A.R. of Egypt, and The Bahamas), however, the consequences of sea level rise (SLR) are potentially catastrophic. For many others, including some of the largest countries (e.g., China), the absolute magnitudes of potential impacts are very large. At the other extreme, many developing countries experience limited impacts. Among regions, East Asia and Middle East/North Africa exhibit the greatest relative impacts. For $1 \mathrm{~m} \mathrm{SLR}$, it is reported that $0.25 \%$ of the Middle East and North African (MENA) coastal area, 3.2\% of the people, 1.49\% of Gross Domestic Product (GDP), 1.94\% of the urban population, $1.15 \%$ of the agriculture, and $3.32 \%$ of the wetlands will be affected. For $5.0 \mathrm{~m} \mathrm{SLR}$ and for Kuwait, it is reported that about $3 \%$ of the coastal area, $2 \%$ of the population, $3.8 \%$ of GDP, $4.7 \%$ of the urban population, almost $0.0 \%$ of the agriculture extent, and $30 \%$ of the wetlands will be affected. Within the Gulf Co-operation Council (GCC) countries, Qatar will be the most impacted country by sea level rise in terms of the percentage of vulnerable land area and in terms of the percentage of wetland affected by SLR followed by Kuwait. As in 2007, there was little evidence that the international community has seriously considered the implications of SLR for population location and infrastructure planning in developing countries. The authors hoped that the reported study results would encourage immediate planning for adaptation.

Coelho et al., 2006 proposed an effective approach to analyze the coastal vulnerability to the coastal region of the Aveiro district, south of Porto, Portugal. During the study they know that the volume of available sediment is deficient compared to the sediment transport capacity, and it was predictable that the erosion situation would become further aggravated in some regions. They proposed a global vulnerability index, which results from the weighting of each independently classified vulnerability parameter.

Al-Jenaid et al., 2008 have assessed the vulnerability and impacts of sea level rise on the Kingdom of Bahrain and provided the adaptation strategy. The total area that might be lost under different SLR scenarios was estimated. It is reported that about $77 \mathrm{~km}^{2}$ of coastal area will be lost if SLR reaches $0.5 \mathrm{~m}$. About $100 \mathrm{~km}^{2}$ coastal area will 
be lost for $1.0 \mathrm{~m} \mathrm{SLR}$ and about $124 \mathrm{~km}^{2}$ for $1.5 \mathrm{~m}$ SLR scenario out of the total area of $780 \mathrm{~km}^{2}$. SLR adaptation policy framework (APF) and adaptation policy initiatives (APIs) are suggested for planners to build upon for reducing the likely effects of SLR in the Kingdom of Bahrain. The framework is composed of four steps, namely, acquisition of information, planning and design, implementation, and monitoring and evaluation. A general policy framework for a national response to SLR is suggested. Additionally, a range of policy adaptation options/initiatives to sustain coastal developments under the likely effects of SLR is recommended.

El Raey (2010) has investigated the impact of sea level rise on the Arab region. It is revealed that the coastal areas in the Arab region are highly vulnerable to the potential impacts of climate change and sea level rise. Proactive action needs to be taken, in terms of both expanding knowledge and cooperation and implementing mitigation and adaptation policies. Although not all of the Arab countries contribute by more than $4.5 \%$ to the total emissions of greenhouse gas (GHG), the coastal zones of most of them are highly vulnerable to the potential impacts of SLR and the expected increased severity and frequency of extreme events. Even though some of the Arab countries have established institutional capabilities for the mitigation of greenhouse gas emissions, none has established such systems for adaptation and self-protection. Excluding Tunisia and Morocco, no integrated national strategic action plans have been established for the vulnerable countries. A strategic assessment and risk reduction of climate change impacts must be carried out as a joint effort through the League of Arab States. An early warning system of Tsunami for the Mediterranean and the Gulf regions must be established through satellite systems. Proactive planning and protection policies and measures should be initiated for vulnerable sectors with particular emphasis on the coastal zone.

AlSahli and AlHasam (2016) have carried out a study on the vulnerability of Kuwaiti coast to SLR. Four scenarios of SLR $(0.5,1,1.5$, and $2 \mathrm{~m})$ were selected to estimate the potential inundated areas and the number of people at risk using remotely sensed data and GIS analysis. CVI was computed based on the lowest scenario of 0.5 m SLR using eight parameters: elevation, slope of the beach, geomorphology, and distance to 20-m isobaths, population, land use, cultural heritage, and transportation. The northern islands of Kuwait, especially Boubyan Island, and the western coast of Kuwait Bay near Doha Port would be highly impacted for $0.5 \mathrm{~m}$ SLR. The number of people at risk due to potential SLR ranges from 65,128 for a SLR of 0.5 and $1 \mathrm{~m}$ to 173,673 for a SLR of $2 \mathrm{~m}$. This is nearly $1.8 \%$ and $4.8 \%$ of the population of Kuwait in 2011, respectively. Most of the coastal areas under inundation risk had a moderate vulnerability index. These areas occupy about $97 \%$ of the areas under inundation risk. Most areas with moderate CVI scores extend over the northern islands (such as Warba and Boubyan Islands) because they are neither populated nor urbanized. The CVI of Kuwait Bay coast and southern coast of Kuwait varied from low to very high. This is an initial study for the area. The authors recommended further study with more socio-economic and physical parameters. The main issue in this study is that the authors did not use wave height and shoreline change rate, which are vital for CVI assessment. These elements were considered in the present study.

Arthur and Garland (2016) have used GIS to estimate the extent of inundation due to SLR for Al Hamra development in Ras Al-Khaimah, which is a large multi-use coastal development project in United Arabian Emirates (UAE). The authors revealed that such study for the entire coastline of Ras Al-Khaimah could be used for the following three purposes:

- Assessing the value of the existing buildings and infrastructures at risk;

- Developing new planning policies such as setback lines, through which the future developments are restricted from flood zones;

- As a tool for emergency preparedness should future, extreme wave events occur.

These are the main purposes for any coastal country, expected to get impact due to SLR. 
Hereher (2016) has carried out a coastal vulnerability study for Saudi Arabian Red seacoast of $1840 \mathrm{~km}$ by using coastal geomorphology, coastal slope, flora and fauna, and socioeconomic factors. It was found that the shorelines are mostly resistant to erosion and inundation by seawater due to the inherent hard nature and relatively high relief in this area. It is also revealed that about $16 \%$ of the red sea coast is highly vulnerable due to global warming and associated sea level rise.

AlSahli (2019) carried out a study to assess the coastal vulnerability of Kuwait for $0.5 \mathrm{~m}, 1.0 \mathrm{~m}, 1.5 \mathrm{~m}$, and $2.0 \mathrm{~m}$ sea level rise. CVI for Kuwait coasts was computed using four physical parameters (i.e., elevation, coastal slope, geomorphology, and distance to $20 \mathrm{~m}$ isobaths) and four socioeconomic parameters (i.e., population, landuse, cultural heritage, and transportation). It is estimated that the total inundated area varied from about $214 \mathrm{~km}^{2}$ at SLR Of $0.5 \mathrm{~m}$ to $498 \mathrm{~km}^{2}$ at SLR of $2 \mathrm{~m}$. It is emphasized that further detailed study is required.

Bu-Qammaz et al., 2020 have developed a knowledge-based system that facilitates the implementation of an Integrated Coastal Zone Management (ICZM) framework in Kuwait. The proposed system is an "Integrated Coastal Zone Management: Knowledge-Based System" (ICZM-KBS), which is a tool created using C\# programming language. The developed tool supports the application of ICZM strategies to safeguard coastal areas from unwanted negative impacts during the coastal space development. The authors have tested this system using a case study provided by Kuwait Environment Public Authority (KEPA) experts, and it was found to be reliable and important to facilitate the ICZM implementation in Kuwait. It is believed that more sustainable marine space can be developed with safeguarding the coastal environment, if this system is further developed with inputs that are more reliable.

Hassan and Hassaan (2020) assessed the impacts of SLR on the geomorphology of the Kuwaiti coastline for two different SLR scenarios based on an integrated analysis model, which involves a range of methods and a composite vulnerability index integrating five criteria. It is found that about $58 \%$ of the total coastal area is susceptible to inundation for 1- and 2-m SLR scenario. It is revealed that $8.3 \%$ of Kuwaiti coastal areas have moderate to high vulnerability levels. It was found that SLR may have significant implications for some Kuwaiti coastal areas including expanding sabkhas, shoreline retreat, changing coastal hydrodynamics, and changing erosion patterns and accelerated weathering process. To avoid these types of impacts in future, the authors recommend the development of a national strategy for adaptation to SLR impact and changing adaptation into development plans.

AlBanai (2020) studied the inundation of Failaka Island in Kuwait for different sea level rise scenarios. It is estimated that for $1 \mathrm{~m}, 2 \mathrm{~m}$, and $3 \mathrm{~m}$ future sea level rise, the expected inundation is about $13 \%, 46 \%$, and $69 \%$, respectively. It is also shown that the eastern part of Failaka Island is more vulnerable to inundation due to sea level rise.

AlMutairi et al., 2021 also studied the environmental and economic impacts of sea level rise for Kuwait's coastal zone for sea level rise scenarios of $0.5,1.0,1.5$, and $2.0 \mathrm{~m}$. It is revealed that the governorate of Hawali and Kuwait city will be more affected than Ahmadi in terms of number of affected people and the residential sector's economic losses. It is found that if sea level would rise from $0.5 \mathrm{~m}$ to $2 \mathrm{~m}, 1.4 \%-4.8 \%$ of Kuwait's coastal zone would be inundated. This would force $0.28 \%-1 \%$ of residents to abandon their homes, which would cause residential losses of $\$ 3,463$ to $\$ 11,142$ million. The authors strongly recommended that the Kuwaiti government should consider the long-term consequences of SLR and initiate a proactive adaptation strategy.

Some of the messages and conclusions from review articles since 2018 on coastal vulnerability assessment studies are provided in Table 1. 
Table 1. Messages from review articles in the area of coastal vulnerability studies.

\begin{tabular}{|c|c|c|}
\hline Review article & Year & Focus of the article and concluding remarks \\
\hline $\begin{array}{l}\text { Bevacqua et al., } \\
2018\end{array}$ & 2018 & $\begin{array}{l}200 \text { articles were reviewed in the area of coastal vulnerability research works. The } \\
\text { authors described the evolution of vulnerability concepts, and the modern definition } \\
\text { of vulnerability. The goal was to provide a well-informed body of knowledge to be } \\
\text { used in the advancement of resilience and increased sustainability in coastal areas. }\end{array}$ \\
\hline $\begin{array}{l}\text { Kantamaneni et } \\
\text { al. (2019) }\end{array}$ & 2019 & $\begin{array}{l}\text { The authors did a review on coastal vulnerability assessment studies carried out over } \\
966 \mathrm{~km} \text { Coastal Andhra Pradesh (CAP), India. They examined the coastal } \\
\text { vulnerability factors and their influence along the CAP region. Based on the } \\
\text { vulnerability assessment and parameters considered for different Indian geographic } \\
\text { locations, it is found that very little has been done to study the overall coastal } \\
\text { vulnerability along this region. }\end{array}$ \\
\hline $\begin{array}{l}\text { de Sherbinin et } \\
\text { al., } 2019\end{array}$ & 2019 & $\begin{array}{l}84 \text { articles were reviewed that map Social vulnerability to climate impacts. The goal } \\
\text { was to identify common approaches to mapping, evaluate their strengths and } \\
\text { limitations, and offer recommendations and future directions. The systematic review } \\
\text { finds some convergence around common frameworks developed by the } \\
\text { Intergovernmental Panel on Climate Change, frequent use of linear index aggregation, } \\
\text { and common approaches to the selection and use of climate and socioeconomic data. } \\
\text { Further, the review identifies limitations such as a lack of future climate and } \\
\text { socioeconomic projections in many studies, insufficient characterization of } \\
\text { uncertainty, challenges in map validation, and insufficient engagement with policy } \\
\text { audiences for those studies that purport to be policy relevant. }\end{array}$ \\
\hline $\begin{array}{l}\text { Toimil et al., } \\
2020\end{array}$ & 2020 & $\begin{array}{l}\text { The authors focused the reviews on (a) traditional practice towards more climate- } \\
\text { aware approaches; (b) developing more comprehensive risk frameworks, and (c) } \\
\text { building bridges between risk assessment and adaptation theory and practice. The } \\
\text { authors recommended that focus is needed on increased observations; the attribution } \\
\text { of coastal impacts to their drivers; enhanced climate projections and their integration } \\
\text { into impact models; more impact assessments at the local scale; dynamic projections } \\
\text { of spatially-distributed exposure and vulnerability; and the exploration of inherently } \\
\text { adaptive options and more practical guidance. }\end{array}$ \\
\hline $\begin{array}{l}\text { Rangel- } \\
\text { Buitrago et al., } \\
2020\end{array}$ & 2020 & $\begin{array}{l}\text { The authors describes the knowledge and information shared by } 32 \text { different articles } \\
\text { appeared as a virtual special issue titled as "Vulnerability Assessments as a Tool for } \\
\text { the Coastal and Marine Hazards Management" in the Journal of Ocean and Coastal } \\
\text { Management. }\end{array}$ \\
\hline
\end{tabular}




\begin{tabular}{|c|c|c|}
\hline $\begin{array}{l}\text { Bukvic et al., } \\
2020\end{array}$ & 2020 & $\begin{array}{l}\text { The authors evaluated the state of coastal vulnerability assessment mapping efforts to } \\
\text { identify the opportunities for advancement and refinement that would support more } \\
\text { cohesive, impactful, and policy-relevant coastal vulnerability studies. The mapping } \\
\text { product based on physical and social vulnerability is analyzed for the scale of } \\
\text { analysis, location, disciplinary focus, conceptual framework, metrics used, } \\
\text { methodological approach, data sources, mapping output, and policy relevance. The } \\
\text { authors provided seven recommendations for the advancement of this field that would } \\
\text { improve Coastal Vulnerability Mapping Assessment's methodological rigor, policy } \\
\text { relevance, and alignment with other vulnerability assessment paradigms. }\end{array}$ \\
\hline $\begin{array}{l}\text { Shah et al., } \\
2020\end{array}$ & 2020 & $\begin{array}{l}\text { The authors revealed that the nature-based solutions (NBS) are increasingly being } \\
\text { implemented as suitable approaches for reducing vulnerability and risk of social- } \\
\text { ecological systems (SES) to hydro-meteorological hazards. The authors confirmed } \\
\text { that very few frameworks have been developed in the context of NBS. Most of the } \\
\text { frameworks have emphasized social systems over ecological systems and literatures } \\
\text { have not explicitly considered the temporal dimension of risk reduction measures. } \\
\text { The authors identified } 135 \text { indicators, which are composed of } 61 \% \text { indicators } \\
\text { representing the social sub-system and } 39 \% \text { representing the ecological sub-system. } \\
\text { The authors proposed an indicator-based vulnerability and risk assessment framework } \\
\text { in the context of NBS (VR-NBS) considering hydro-meteorological hazards and NBS } \\
\text { and recommend that it can be adapted for other natural hazards and different types of } \\
\text { risk reduction measures. }\end{array}$ \\
\hline $\begin{array}{l}\text { Busayo et al., } \\
2020\end{array}$ & 2020 & $\begin{array}{l}\text { The authors have provided ideas for climate change adaptation (CCA) and disaster } \\
\text { risk reduction (DRR) to enhance sustainable planning outcome in the coastal region. } \\
\text { The important policy, planning, practice, and programs for CCA and DRR are } \\
\text { revealed. }\end{array}$ \\
\hline $\begin{array}{l}\text { Anfuso et al., } \\
2021\end{array}$ & 2021 & $\begin{array}{l}205 \text { published articles were reviewed and the authors examined the different } \\
\text { vulnerability indexes, built up with forcing and morphological variables in both } \\
\text { coastal sensitivity and vulnerability studies, together with the main coastal adaptation } \\
\text { strategies used to reduce biophysical vulnerability. The analysis demonstrated that the } \\
\text { more sophisticated the index or the model, the more data are required. So, this point } \\
\text { highlights the need for observations, continuous measurements, and open-access } \\
\text { databases. An integrated perspective in several dimensions must be performed, } \\
\text { including integration across change drivers (climate and non-climate), across sectors, } \\
\text { impacts and responses, across space and time dimensions, and across institutions } \\
\text { (including levels of government). In particular, the adaptation strategies can be } \\
\text { successfully implemented by an informed, engaged and prepared community with } \\
\text { active participation of different stakeholders, even the more disadvantaged and } \\
\text { marginalized groups. }\end{array}$ \\
\hline
\end{tabular}


There are not many studies on CVI in the Gulf Co-operation Council regions and especially in Kuwait. A scientifically sound study on CVI will help decision makers for preparing the adaptation and resilient strategy among the people living closer to the coastal area of Kuwait. This is the main motivation for the present study.

\section{METHODOLOGY}

The total coastal length of Kuwait is divided into two groups, containing 162 coastal segments. Group I contains 138 segments and covers the coastal area of the mainland of Kuwait, Boubyan, and Failaka Island. Group II contains 24 coastal segments and covers the coastal areas of Umm Al-Maradim, Qaru, and Kubbar Islands. The data required for each segment for CVI assessments are geomorphology, historical shoreline change rate, regional coastal slope, relative sea-level change, mean significant wave height, and mean tidal range. According to Thieler and Hammar-Klose (2000), the CVI is assessed by

$\mathrm{CVI}=[(\mathrm{a} \cdot \mathrm{b} \cdot \mathrm{c} \cdot \mathrm{d} \cdot \mathrm{e} \cdot \mathrm{f}) / 6],{ }^{1 / 2}$

where $\mathrm{a}, \mathrm{b}, \mathrm{c}, \mathrm{d}$, e, and $\mathrm{f}$ are the vulnerability ranking for geomorphology, historical shoreline change rate, regional coastal slope, mean significant wave height, mean tidal range, and relative sea-level change, respectively. The vulnerability ranking for each coastal segment and for each parameter is assigned between 1 and 5 (Thieler and Hammar-Klose, 2000) based on the magnitude of the respective parameters, Table 2.

Table 2.Typical ranges of vulnerability ranking of different variables used by United States Geological Survey (Gornitz et al., 1991).

\begin{tabular}{|l|c|c|c|c|c|}
\hline \multicolumn{1}{|c|}{ Variables } & $\begin{array}{c}\text { Very low } \\
\mathbf{1}\end{array}$ & $\begin{array}{c}\text { Low } \\
\mathbf{2}\end{array}$ & $\begin{array}{c}\text { Moderate } \\
\mathbf{3}\end{array}$ & $\begin{array}{c}\text { High } \\
\mathbf{4}\end{array}$ & $\begin{array}{c}\text { Very high } \\
\mathbf{5}\end{array}$ \\
\hline $\begin{array}{c}\text { Rocky } \\
\text { cliffed } \\
\text { coasts, } \\
\text { Fjords }\end{array}$ & $\begin{array}{c}\text { Medium } \\
\text { cliffs, } \\
\text { indented } \\
\text { coasts }\end{array}$ & $\begin{array}{c}\text { Low cliffs, } \\
\text { glacial } \\
\text { drift, } \\
\text { alluvial } \\
\text { plains }\end{array}$ & $\begin{array}{c}\text { Cobble } \\
\text { beaches, } \\
\text { estuary, } \\
\text { lagoon }\end{array}$ & $\begin{array}{c}\text { Barrier beaches, } \\
\text { sand beaches, salt } \\
\text { marsh, mud flats, } \\
\text { deltas, mangrove, } \\
\text { and coral reefs }\end{array}$ \\
\hline $\begin{array}{c}\text { (b) Historical shoreline change } \\
\text { rate (m/yr.)(erosion is -ve } \\
\text { and accretion is +ve) }\end{array}$ & $>2.0$ & $1.0-2.0$ & $-1.0-1.0$ & $-2.0--1.0$ & $<-2.0$ \\
\hline $\begin{array}{c}\text { (c) Regional coastal slope (\%) } \\
\text { (e) }\end{array}$ & $>1.20$ & $1.20-0.90$ & $0.90-0.60$ & $0.60-0.30$ & $<0.30$ \\
\hline (d) Mean wave height (m) & $<0.5$ & $0.5-0.7$ & $0.7-0.9$ & $0.9-1.1$ & $>1.1$ \\
\hline (e) Mean tide range (m) & $>4.0$ & $3.0-4.0$ & $2.0-3.0$ & $1.0-2.0$ & $<1.0$ \\
\hline $\begin{array}{c}\text { (f) Relative sea level change } \\
\text { (mm/yr.) }\end{array}$ & $<1.8$ & $1.8-2.5$ & $2.5-3.0$ & $3.0-3.4$ & $>3.4$ \\
\hline
\end{tabular}


Unlike, USA, Canada, Japan, India or Australia, Kuwait is a small coastal country and the variation of future relative sea level change at different coastal locations from north to south is expected to be the same, the relative sea-level change is not an appropriate parameter, and it can be omitted from Equation 1. Since the beach soil particle size is one of the most important parameters for coastal erosion (smaller sized particles erode easily), the data is collected based on the field works for all the 162 locations, and it is incorporated in Equation 1. The shoreline change rate was assessed for all the 138 locations in group 1, since the old and latest remote sensing pictures are available in Google map. For Umm Al-Maradim, Qaru, and Kubbar Islands, only the latest remote sensing pictures are available in Google map, and there is no old map available in Google. Hence, the CVI for group 2 locations are assessed based on

$\mathrm{CVI}=[(\mathrm{a} \cdot \mathrm{c} \cdot \mathrm{d} \cdot \mathrm{e} \cdot \mathrm{f}) / 5] .^{1 / 2}$

Table 3 is now modified to suit the Kuwaiti coastal conditions.

Table 3. Ranges of vulnerability ranking of the different variables used for physical vulnerability assessment of Kuwaiti coastal area.

\begin{tabular}{|c|c|c|c|c|c|}
\hline Variables & $\begin{array}{l}\text { Very low } \\
1\end{array}$ & $\begin{array}{c}\text { Low } \\
2\end{array}$ & $\begin{array}{l}\text { Moderate } \\
\quad 3\end{array}$ & $\begin{array}{l}\text { High } \\
4\end{array}$ & $\begin{array}{l}\text { Very high } \\
5\end{array}$ \\
\hline (a)Geomorphology & $\begin{array}{l}\text { Rocky } \\
\text { coast }\end{array}$ & $\begin{array}{c}\text { Mix of } \\
\text { sandy and } \\
\text { rocky coast }\end{array}$ & Low cliffs & $\begin{array}{l}\text { Cobble } \\
\text { beaches }\end{array}$ & $\begin{array}{c}\text { Sandy beach, } \\
\text { sandy beach with } \\
\text { coral bed, or with } \\
\text { a lot of slipways, } \\
\text { or with beach } \\
\text { houses near HWL }\end{array}$ \\
\hline $\begin{array}{l}\text { (b) Shoreline change rate } \\
\text { (m/yr.) }\end{array}$ & $>2$ & 2 to 1 & 1 to -1 & -1 to -2 & $<-2$ \\
\hline (c) Coastal slope (\%) & $>1.2$ & $0.9-1.2$ & $0.6-0.9$ & $0.3-0.6$ & $<0.3$ \\
\hline $\begin{array}{l}\text { (d) Maximum significant wave } \\
\text { height }(m)\end{array}$ & $<0.5$ & $0.5-1.0$ & $1.0-1.5$ & $1.5-2$ & $>2$ \\
\hline (e) Maximum tidal range $(\mathrm{m})$ & $<2.5$ & $2.5-3.0$ & $3.0-3.5$ & $3.5-4.0$ & $>4.0$ \\
\hline $\begin{array}{l}\text { (f) Grain size of landward soil, } \\
\mathrm{D}_{50}(\mathrm{~mm})\end{array}$ & $>1.0$ & $0.75-1.0$ & $0.5-0.75$ & $0.25-0.5$ & $<0.25$ \\
\hline
\end{tabular}


In the above table, from geomorphology point of view, rocky coasts have significant resistance for erosion and hence take very low vulnerability and fine sandy beaches erode easily and take very high vulnerability ranking of 5 . A site with already high shoreline change rate is expected to continue with similar trend and hence the locations with annual erosion rate of more than $2 \mathrm{~m}$ are assigned high vulnerability ranking of 5 and locations with more than $2 \mathrm{~m} / \mathrm{yr}$. of sediment accretion is assigned low vulnerability rank of 1 .A coastal segment with slope of less than $0.3 \%$ invites wide inundation for future sea level rise compared to a coast with steep slope (say more than $1.2 \%$ slope of the coast). This is because, for $0.3 \%$ slope, $1 \mathrm{~m}$ sea level rise will result in permanent inundation of $300 \mathrm{~m}$ coastal width, whereas, for $1.2 \%$ slope, it will be only $120 \mathrm{~m}$. Hence, the former is given high vulnerability ranking of 5 , and the later one is given low vulnerability ranking of 1 . Similarly, a coastal area with high tidal variation will experience more flooding and the coastal segment with less tidal fluctuation will experience less flooding. In Kuwait, the highest spring tide is about $4.0 \mathrm{~m}$ in the northern part of Arabian Gulf. Hence, the areas around Boubyan and northern coastal area of the mainland are given high vulnerability ranking from tidal variation point of view. The southern coastal areas of Kuwait experience maximum tidal variation of about $2.5 \mathrm{~m}$ during spring tide and hence are given low vulnerability value of 1 . Higher waves have more energy and they can erode the coast easily. Hence, the islands in the southern marine area of Kuwait are given high vulnerability ranking of 5, since they experience maximum waves of more than $2.0 \mathrm{~m}$. On the other hand, the northern parts of Kuwait (Boubyan Island, Failaka Island, northern coastal area of Kuwait, etc.) experience maximum wave heights of less than $1.0 \mathrm{~m}$ and assigned vulnerability ranking of 1 . Finally, if the beach soil is very fine, they can be moved easily by waves and tide induced currents, which will result in erosion. Hence, the coasts with fine sands ( $\mathrm{D}_{50}$ less than $0.25 \mathrm{~mm}$ ) are assigned with high vulnerability ranking of 5 and beaches with coarse sand $\left(\mathrm{D}_{50}>1.0 \mathrm{~mm}\right)$ are assigned with vulnerability ranking of 1 , since more hydrodynamic energy is needed to transport such soils. In this table, $\mathrm{D}_{50}$ is defined as the soil size such that $50 \%$ of the soils are less than $\mathrm{D}_{50}$ in size and $50 \%$ are more than $\mathrm{D}_{50}$ in size. Quality data collection is most important for CVI assessment. For the present study, the source of the data for the parameters specified in Table 3 is shown in Table 4. The research team has spent more than 1 year visiting all the 162 coastal segments to collect the geomorphology, beach slope survey, and soil sample collection for analysis. 26 field visits (from 24.10 .2017 to 15.8 .2019 ) were carried out for collecting the data from all these162 coastal segments of Kuwait.

Table 4. The source of data for CVI assessment for Kuwaiti coast.

\begin{tabular}{|c|c|c|}
\hline \multicolumn{2}{|r|}{ Variables } & Source of data \\
\hline \multicolumn{2}{|c|}{ (a) Geomorphology } & $\begin{array}{l}\text { Field visits, field photos, and geomorphological } \\
\text { observations }\end{array}$ \\
\hline & Shoreline change rate $(\mathrm{m} / \mathrm{yr}$.) & $\begin{array}{l}\text { Google map (satellite maps during 2005, 2011, and } \\
\text { 2017) }\end{array}$ \\
\hline & Coastal slope $(\%)$ & Beach profiling survey for all 162 segments \\
\hline (d) & Maximum significant wave height $(\mathrm{m})$ & $\begin{array}{l}\text { Coastal information system (Al-Salem and Rakha, } \\
\text { 2005, and Al-Salem and Al-Rashid, 2016, }\end{array}$ \\
\hline & Maximum tidal range $(\mathrm{m})$ & $\begin{array}{l}\text { Coastal information system (Al-Salem and Al- } \\
\text { Rashid, 2016) }\end{array}$ \\
\hline & Grain size of landward soil, $\mathrm{D}_{50}(\mathrm{~mm})$ & Field soil collection and sieve analysis in the lab \\
\hline
\end{tabular}


For group 1 (138 coastal segments), the minimum expected value for CVI occurs when $\mathrm{a}=\mathrm{b}=\mathrm{c}=\mathrm{d}=\mathrm{e}=\mathrm{f}=1$, and its value is 0.408 , and the maximum value of the CVI occurs when $\mathrm{a}=\mathrm{b}=\mathrm{c}=\mathrm{d}=\mathrm{e}=\mathrm{f}=5$, and the value is 51.02. For group 2 (24 coastal segments in Umm Al-Maradim, Qaru, and Kubbar Islands), with 5 input parameters, the minimum expected value of CVI is 0.25 , and the maximum expected value is 25 . From the actual CVI assessment for the 138 locations of group 1, the minimum value of CVI obtained is 2.78 and the maximum value obtained is 16.04. Similarly, for the 24 coastal segments of small Island locations in-group 2, the minimum value of CVI obtained is 1.41 and the maximum value obtained is 7.75 . The CVI ranking needs to be done based on these ranges and is given in Table 5 and Table 6 for group 1, and group 2 locations.

Table 5. Ranking for different ranges of CVI values for the 138 locations of mainland, Boubyan, and Failaka Islands in group 1.

\begin{tabular}{|c|c|c|c|}
\hline CVI value & Vulnerability & Rank & Color code \\
\hline Less than 4 & Very low & 1 & Green \\
\hline 4 to 6 & Low & 2 & Blue \\
\hline 6 to 8 & Moderate & 3 & Yellow \\
\hline 8 to 10 & High & 4 & Orange \\
\hline More than 10 & Very high & 5 & Red \\
\hline
\end{tabular}

Table 6. Ranking for different ranges of CVI values for the 24 locations of Umm Al-Maradim, Qaru, and Kubbar Islands in group 2.

\begin{tabular}{|c|c|c|c|}
\hline CVI value & Vulnerability & Rank & Color code \\
\hline Less than 2 & Very low & 1 & Green \\
\hline 2 to 3 & Low & 2 & Blue \\
\hline 3 to 4 & Moderate & 3 & Yellow \\
\hline 4 to 5 & High & 4 & Orange \\
\hline More than 5 & Very high & 5 & Red \\
\hline
\end{tabular}

\section{RESULTS AND DISCUSSIONS}

The CVI maps were prepared for Kuwait. In addition, sub-maps for different coastal stretches were prepared for a closer view and better understanding of the coastal vulnerability. Fig. 3 is the CVI map for Kuwait. From the ranking for different ranges of CVI values for the 138 locations of mainland, Boubyan, and Failaka Island, it is found that $5 \%$ of the Kuwaiti coastal areas in this group are very low vulnerable; $34 \%$ of the coastal areas are low vulnerable; $31 \%$ of the coastal areas are moderately vulnerable; $18 \%$ of the coastal areas are highly vulnerable; and $12 \%$ of the coastal areas are very highly vulnerable. 


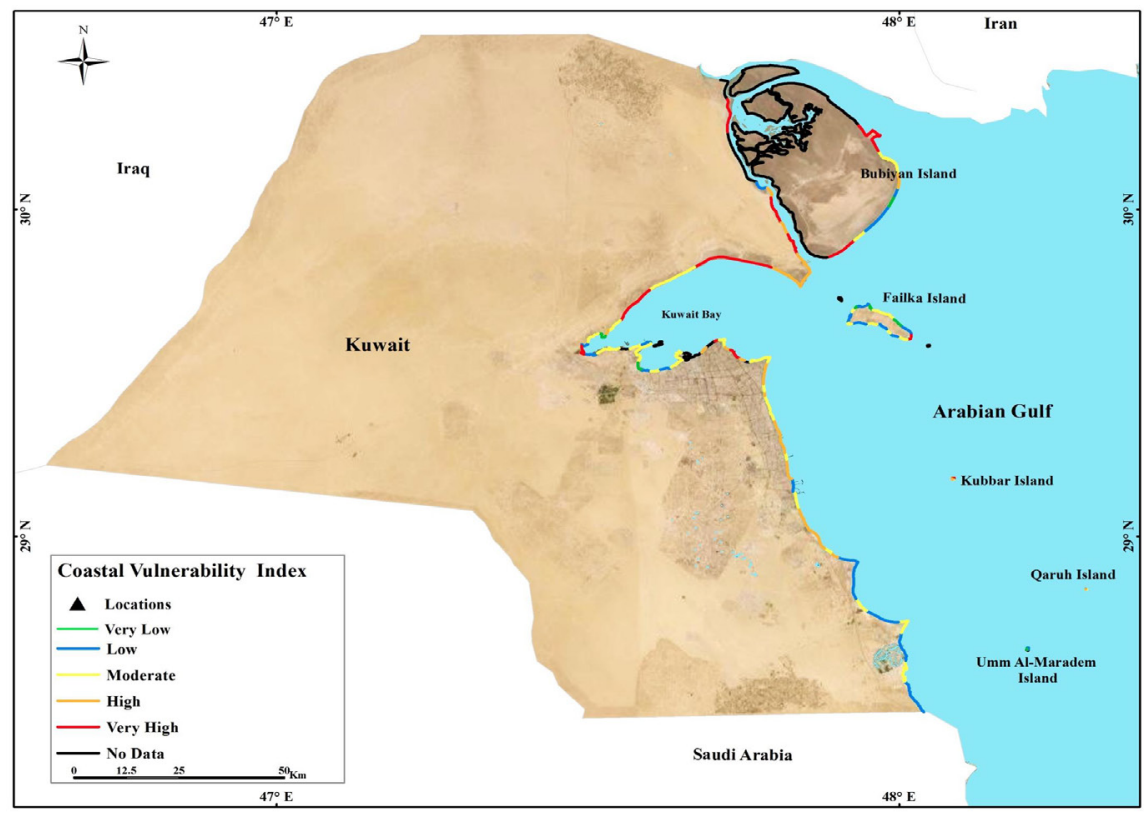

Figure 3. Coastal Vulnerability Index map for Kuwait.

Fig. 4 is a closer view of the CVI map for the northern part of Kuwaiti mainland and Boubyan Island. The area around the Boubyan port and southern part of the Island is physically very high vulnerable due to the combined effect of high tidal range, shoreline change rate, and smaller grain size of soil on the coast.

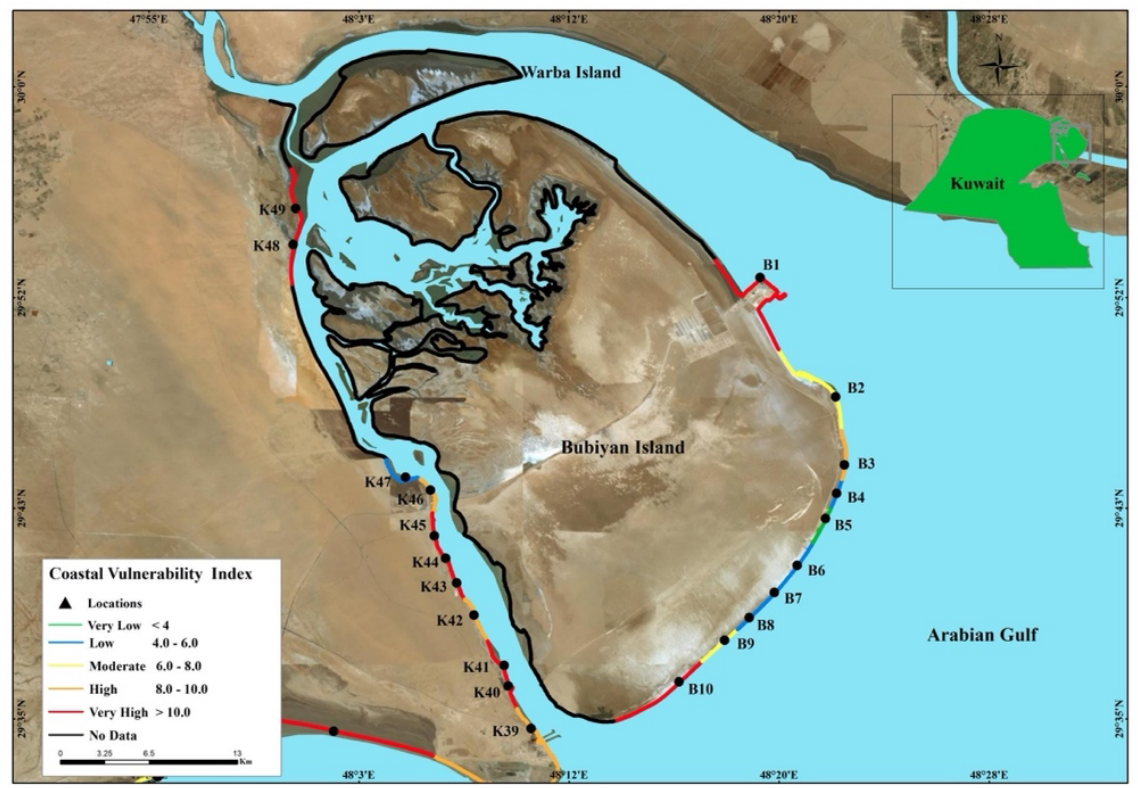

Figure 4. Coastal Vulnerability Index map for coasts in Boubyan Island. 
Fig. 5 shows the Coastal Vulnerability Index map for Failaka Island. The southeastern part of this Island has very high CVI value. The beach slope of the coast at FA11 in Fig. 5 is greater than $0.22 \%$. The coasts around FA14, FA18, and FA20 holds very low vulnerability index and the main contributor is the steep slope.

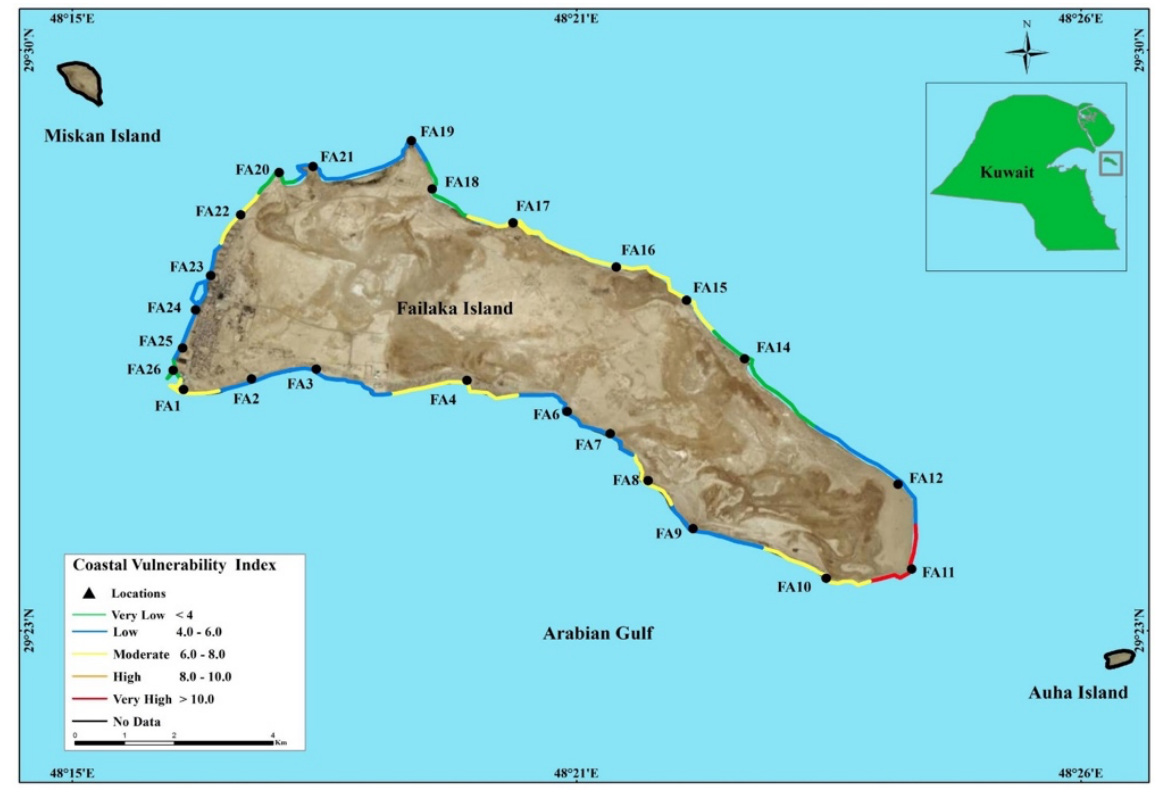

Figure 5. Coastal Vulnerability Index map for coasts in Failaka Island.

Fig. 6 shows the Coastal Vulnerability Index for Kubbar Island. The north and northeastern parts of Kubbar Island are very highly vulnerable mainly due to the presence of fine sandy beaches, which could erode easily. The other coastal areas hold high or moderate CVI ranking.

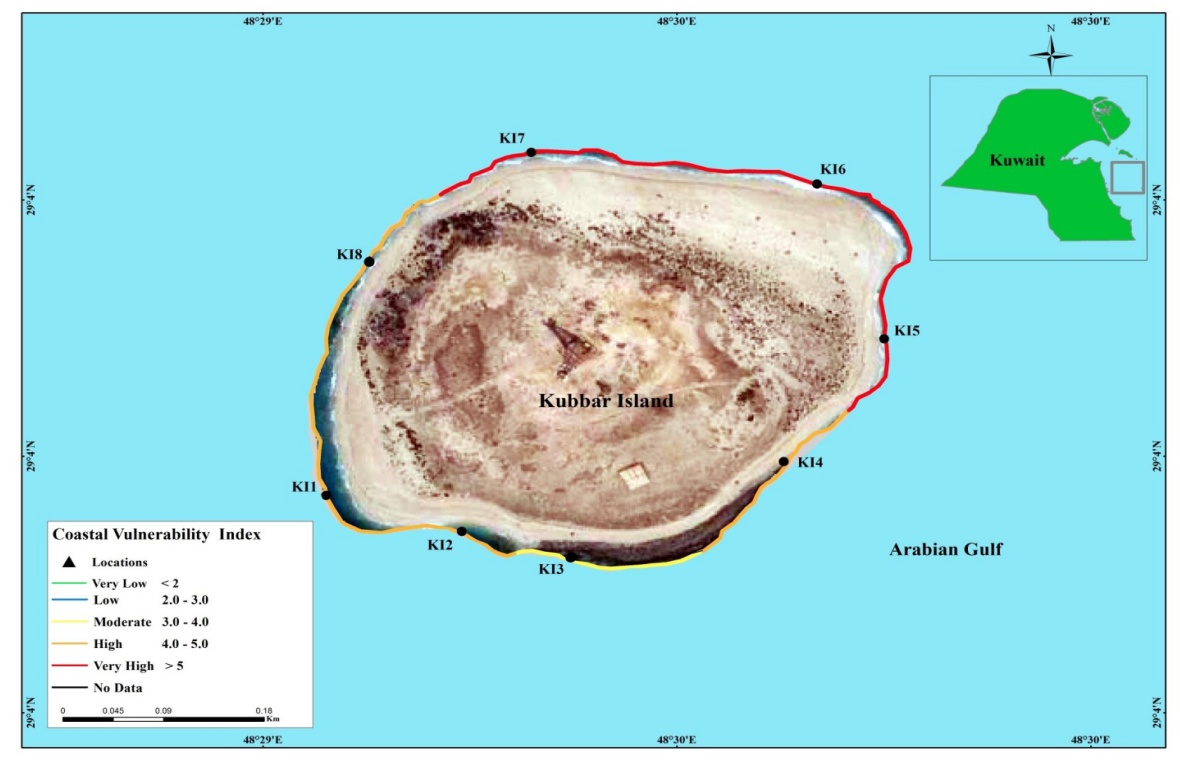

Figure 6. Coastal Vulnerability Index map for coasts in Kubbar Island. 
Figure 7 shows the Coastal Vulnerability Index for Qaruh Island. The northwestern part of Qaruh Island is highly vulnerable mainly due to step beach slope and other parts are moderately vulnerable.

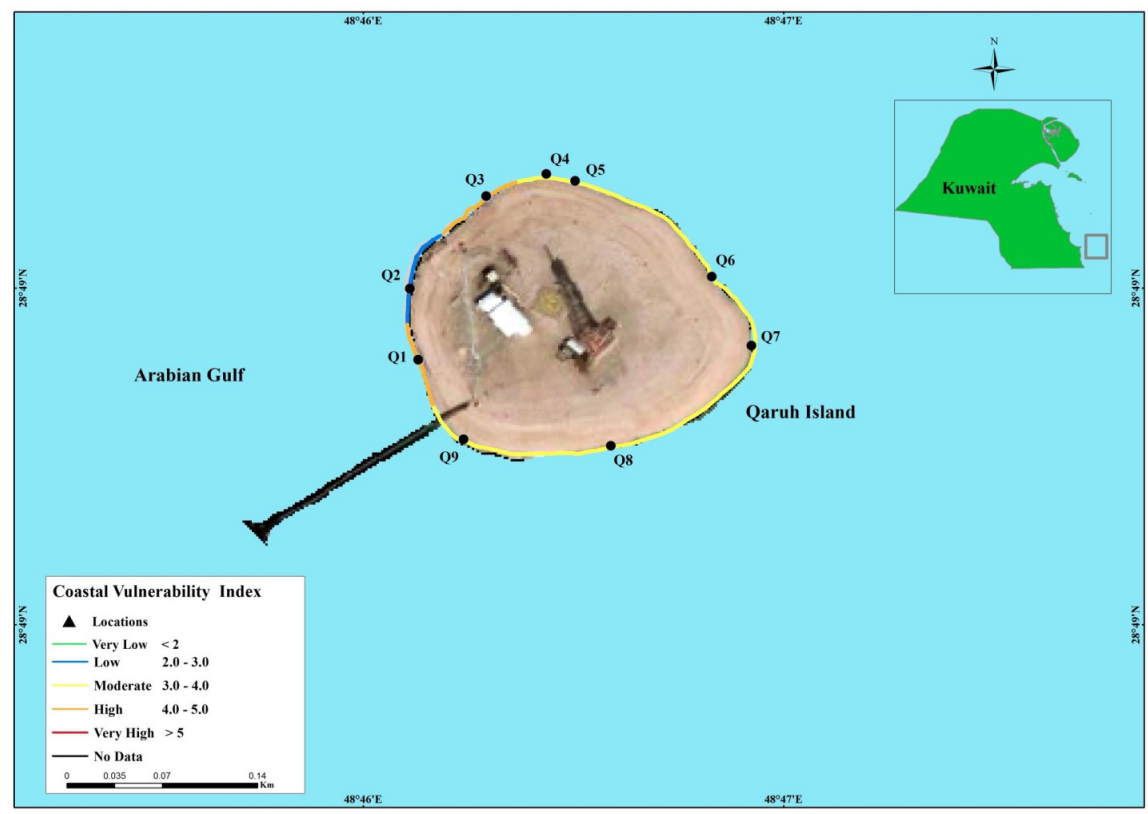

Figure 7. Coastal Vulnerability Index map for coasts in Qaruh Island.

Fig. 8 shows the Coastal Vulnerability Index for Umm Al-Maradim Island. Umm Al-Maradim is in general less vulnerable, since it is an island with rocky coast.

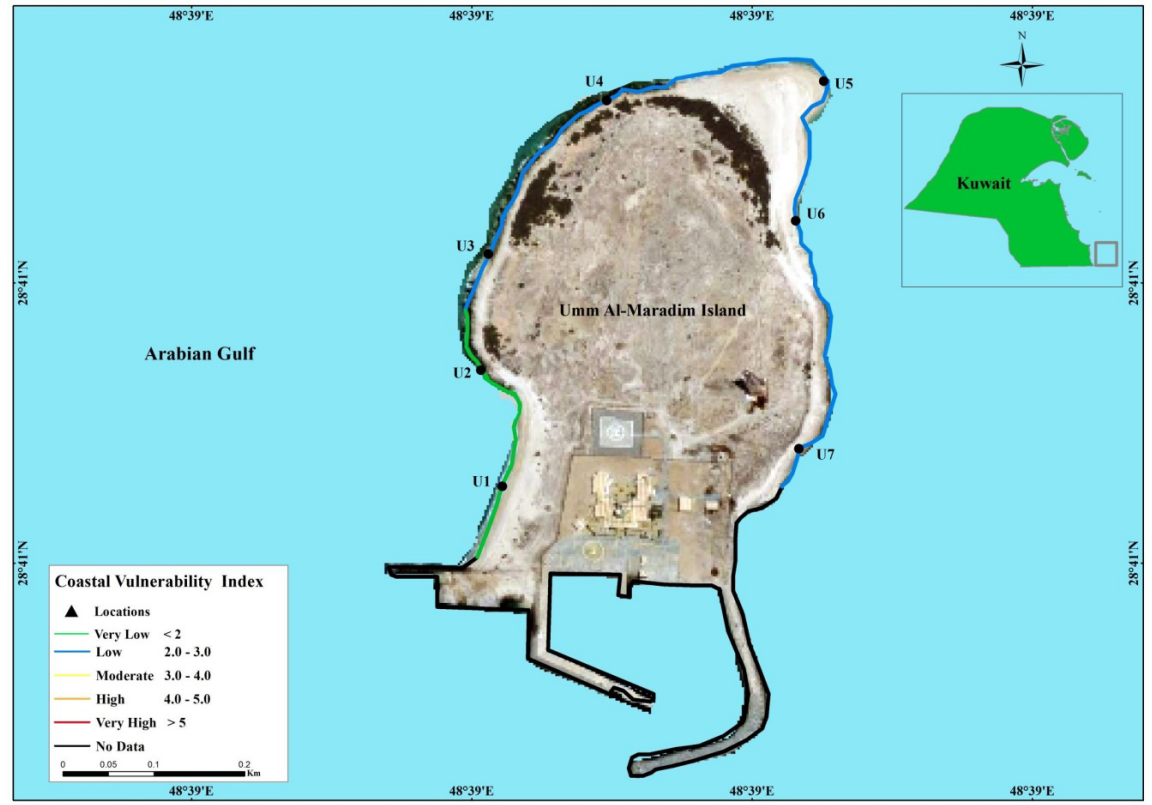

Figure 8. Coastal Vulnerability Index map for coasts in Umm Al-Maradim Island. 
From the ranking for different ranges of CVI values for the 24 locations of Umm Al-Maradim, Qaru, and Kubbar Islands, it is found that $8 \%$ of the coastal areas in these Island groups are very low vulnerable; $21 \%$ of the coastal areas are low vulnerable; $38 \%$ of the coastal areas are moderately vulnerable; $21 \%$ of the coastal areas are highly vulnerable; and $12 \%$ of the coastal areas are very highly vulnerable.

Fig. 9 reveals the Coastal Vulnerability Index for Kuwait Bay coastal segments. Some areas in the northern part of the Kuwait Bay are highly vulnerable due to the combined effect of all influencing parameters and especially due to very mild beach slope, which will allow a wide permanent inundation for the future sea level rise.

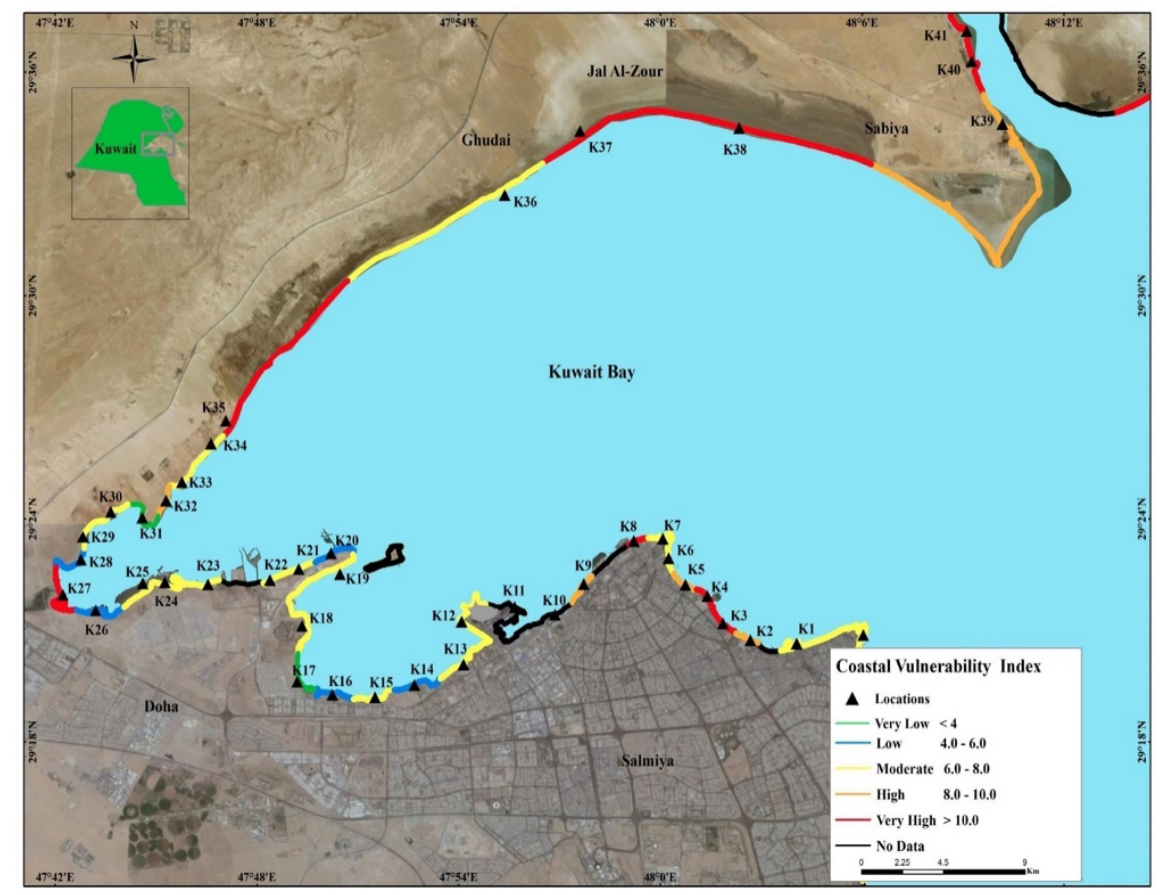

Figure 9. Coastal Vulnerability Index map for coasts around Kuwait Bay.

Fig.10 shows the Coastal Vulnerability Index for Kuwait main land-South. It is found that certain coastal areas are highly vulnerable and some areas are low vulnerable due to the combined contribution of the different input parameters, especially the wave height and soil particle sizes on the beach. 


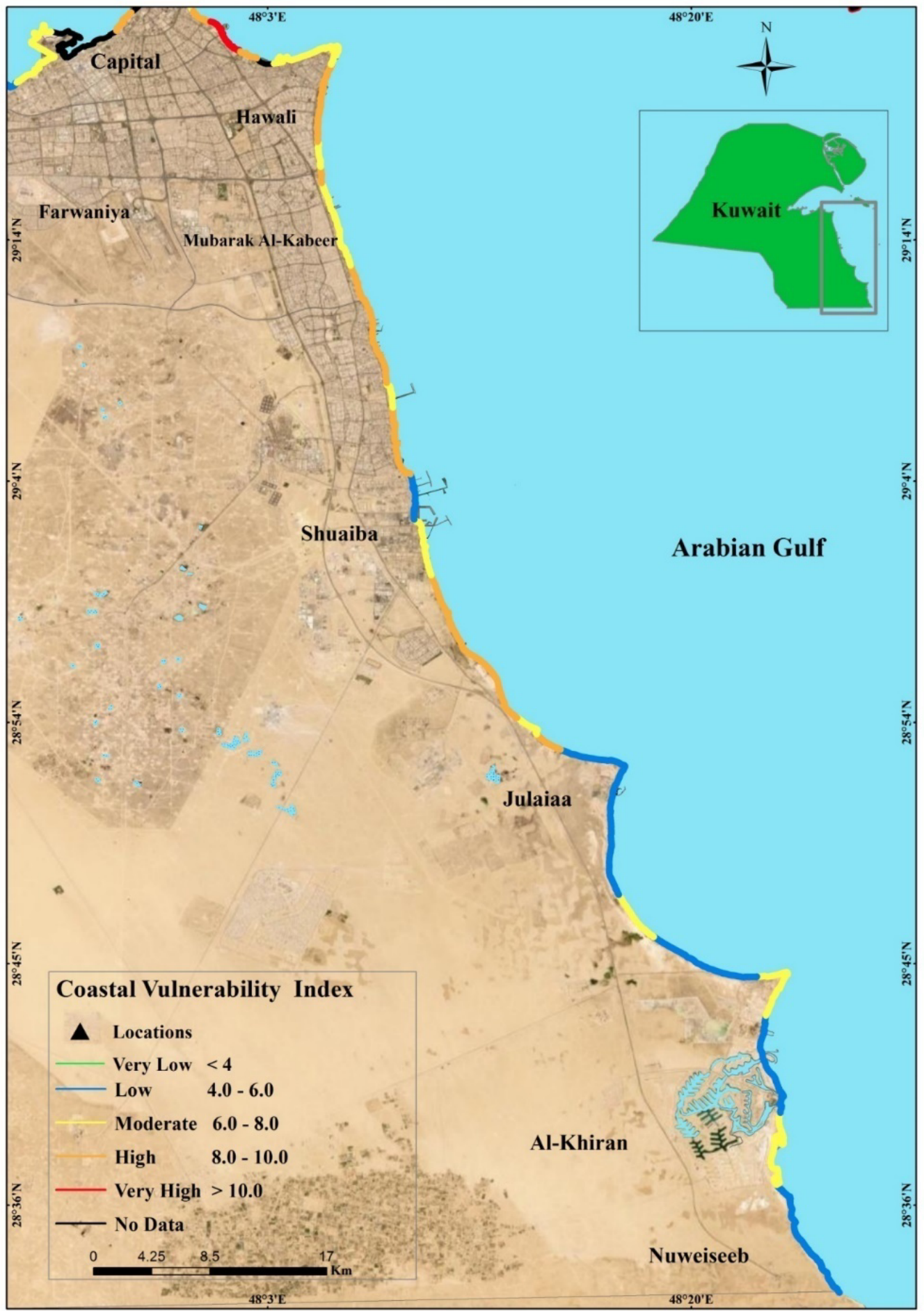

Figure 10. Coastal Vulnerability Index map for coasts in the Kuwait mainland south. 


\section{THE PROPOSED MAJOR DEVELOPMENT PLANS OF THE COASTAL AREAS IN KUWAIT AND STRATEGY FOR RESILIENCE ACTIVITIES}

From this study, the physical vulnerability ranking was estimated for all 162 coastal segments, which covers the coastal area of Kuwait main land as well as the Islands. Kuwait is planning for developing Boubyan Island as well as Failaka Island as tourism hub. The plan to develop Silk city and Boubyan Island with a budget of US \$450 billion is in pipeline (www.beltandroad.news). Since the highly vulnerable coastal spots are identified in this study, it is possible to plan and act before starting the development activities. Among the different physical parameters responsible for coastal vulnerability, it is not possible to change geomorphology, wave heights, and tidal variations, since they are the parameters controlled by nature. The other parameters such as shoreline change rate, coastal slope, and grain size of the beach soils can be changed. For example, creating a technically sound beach erosion protection using hard or soft solutions would change the shoreline change rate from eroding coast to either stable coast or accreting coast. An existing steep beach can be converted into mild sloped beach by nourishing it with suitable soil. Similarly, the land elevation on the coastal area can be increased, so that the future sea level rise will not cause permanent inundation of the land property. If the existing beach soil is very fine sand, it can be replaced with coarse soil, if the borrow pit area is not far away from the site. These types of corrective measures can be planned by keeping in mind the CVI index values of the coastal segments from the present study, the development plans by the government, and the economics needed for the resilience activities as suggested above.

\section{CONCLUSION}

A detailed study was carried out to assess the Coastal Vulnerability Index for Kuwaiti coast. The complete Kuwaiti coastal area is divided into 162 coastal segments, which is divided into group 1, with 138 segments for Kuwaiti mainland coast, Boubyan, and Failaka Island, and group 2 with 24 segments for Umm Al-Maradim, Kubbar, and Qaru Islands. The field data is collected for these 162 segments for coastal geomorphology, beach slope, and the soil particle sizes. The shoreline change rate is assessed using remote sensing data and the wave and tidal data were extracted from the Coastal Information Systems developed and maintained by KISR (Al-Salem and Al-Rashid, 2016). The coastal vulnerability index of these 162 coastal segments is derived based on a modified formula of USGS (Thieler and Hammar-Klose, 2000). The coastal locations with high and low vulnerability were identified. It was found that within group 1 coastal locations, 5\% of the Kuwaiti coastal areas are very low vulnerable; $34 \%$ coastal areas are low vulnerable; $31 \%$ coastal areas are moderately vulnerable; $18 \%$ coastal areas are highly vulnerable; and $12 \%$ coastal areas are very highly vulnerable. In group 2, $8 \%$ of the coastal areas are very low vulnerable; $21 \%$ coastal areas are low vulnerable; $38 \%$ coastal areas are moderately vulnerable; $21 \%$ coastal areas are highly vulnerable; and $12 \%$ of the coastal areas are very highly vulnerable. A possible resilience strategy for the highly vulnerable coastal areas in Boubyan and Failaka Island is suggested since Kuwait is planning for major developments in these two Islands. The result of this study on physical vulnerability of the Kuwaiti coast will be useful for advance planning for remedial action to reduce the coastal vulnerability and for allocation of budget for suitable resilient measures to reduce the vulnerability.

\section{ACKNOWLEDGEMENT}

The authors would like to thank the upper management of Kuwait Institute for Scientific Research (KISR) and Kuwait for the logistics and Kuwait Environment Public Authority (KEPA) for the support. The authors also thank the staffs from both KISR and KEPA for their support and help during the field data collection and analysis. 


\section{REFERENCES}

AlBanai, J. A. 2020. Sea level rise projections for Failaka Island in the State of Kuwait. Transactions of Maritime Science 02: 236-247.

Al-Jenaid, S. S., Bahnassy, M., Nasr, S. \& El Raey, M. 2008. Vulnerability assessment and adaptation to the impacts of sea level rise on the Kingdom of Bahrain. Mitig. Adapt. Strat. Glob. Change 13:87-104.

Al-Mutairi, N., Alsahli, M., El-Gammal, M., Ibrahim, M. \&Samra, R. A. 2021. Environmental and economic impacts of rising sea levels: A case study in Kuwait's coastal zone. Ocean and Coastal Management 205, 105572. https://doi.org/10.1016/j.ocecoaman.2021.105572.

Alsahli, M. M.M. \& AlHasem, A. M. 2016. Vulnerability of Kuwait coast to sea level rise. Geografisk Tidsskrift-Danish Journal of Geography, 116(1):56-70. DOI:10.1080/00167223.2015.1121403.

AISahli, M. M. M. (2019). Kuwait National Adaptation Plan (NAP) Project: Climate Risks and Vulnerability Profile Kuwait. Technical Report, J January 2019, DOI: 10.13140/RG.2.2.14796.26245.

Al-Salem, K.\& Rakha. K. 2005. Verification of a WAM Model for the Arabian Gulf. Arabian Coast 2005 Conference, Dubai, 15 October 2005.

Al-Salem, K.\& Al-Rashed, A. 2016. Updating the Database of KISR's Coastal Information System (C.I.S.) by Using Numerical Techniques. Kuwait Institute for Scientific Research. Report No. KISR-13793, Kuwait.

Addo, K. A. 2013. Assessing coastal vulnerability index to climate change: the case of Accra-Ghana. Journal of Coastal Research 65(sp2): 1892-1897.

Anfuso, G., Postacchini, M., Luccio, D., \& Benassai, G. 2021. Coastal Sensitivity/Vulnerability Characterization and Adaptation Strategies: A Review. J. Mar. Sci. Eng. 9, 72. https://doi.org/10.3390/ jmse9010072.

Arthur, R. M.\& Garland, G. G. 2016. Predicting the extent of inundation due to sea level rise: Al Hamra development, Ras Al Khaimah, UAE. A Pilot Project. Missegmentanea Geographica-Regional studies on development. 20(2): 25-31. ISSN: 2084-6118, DOI: 10.1515/mgrsd-2016-0012.

Bevacqua, A., Yu, D., \& Zhang, Y. 2018. Coastal vulnerability: Evolving concepts in understanding vulnerable people and places. Environmental Science and Policy 82: 19-29.

Bu-Qammaz, A., AlHamed, S., AlNasser, F., \& Alkhalidi, M. 2020. Integrated Coastal Zone Management in Kuwait: A Knowledge-Based System Model. Journal of Engg. Research Vol. 8 No. (4) December 2020 pp. 29-44. DOI: https://doi.org/10.36909/jer.v8i4.7931

Busayo, E. T., \& Kalumba, A. M. 2020. Coastal climate change adaptation and disaster risk reduction: a review of policy, programme and practice for sustainable planning outcomes. Sustainability 12(16):6450.

Bukvic, A., Rohat, G., Apotsos, A., \& de Sherbinin, A. A. 2020. Systematic Review of Coastal Vulnerability Mapping. Sustainability 12, 2822.

Cheong, S. M. 2008. A new direction in coastal management. Marine Policy32:1090-1093. 
Coelho, C., Silva, R., Veloso-Gomes, F., \& Pinto, F. T. 2006. A vulnerability analysis approach for the Portuguese West Coast. WIT Transactions on Ecology and the Environment 91: 251-262, DOI:10.2495/risk060241.

Dasgupta, S., Laplante,B., Meisner, C.\& Yan, J. 2007. The impact of sea-level rise on developing countries: A comparative study. World Bank policy research working paper 4136, Feb. 2007.

de Sherbinin, A., Bukvic, A., Rohat, G., Gall, M., McCusker, B., Preston, B., Apotsos, A., Fish, C., Kienberger, S., Muhonda, P., Wilhelmi, O., Macharia, D., Shubert, W., Sliuzas, R., Tomaszewski, B. \& Zhang. S. 2019. Climate vulnerability mapping: A systematic review and future prospects. Wiley Interdisciplinary Reviews: Climate Change 10(5): e600. DOI: 10.1002/wcc.600.

Diez, P. G., Perillo, G. M.\& Piccolo, M. C. 2007. Vulnerability to sea-level rise on the coast of the Buenos Aires Province. Journal of Coastal Research 23(1): 119-126.

Doukakis, E. 2005. Risks in coastal zone by climate change and tsunami. In Working Meeting Risk assessment in the Corinthian Gulf, Derveni, Greece.

Dow, K. \& Downing, T. E. 2011.The Atlas of Climate Change: Mapping the World's Greatest Challenge. University of California Press, Oakland, California. ISBN: 978-0-520-26823-4.

Dronkers, J., Gilbert, J. T. E., Butler, L. W., Carey, J. J., Campbell, J., James, E., McKenzie, C., Misdorp, R., Quin, N., Ries, K.L., Schroder, P. C., Spradley, J. R., Titus, J. G., Vallianos, L.\& von Dadelszen, J. 1990. Strategies for adaptation to sea level rise. Report of the IPCC Coastal zone management subgroup: Intergovernmental Panel on Climate Change. Geneva.

Duriyapong, F.\& Nakhapakorn, K. 2011. Coastal vulnerability assessment: a case study of Samut Sakhon coastal zone. Sonklanakarin Journal of Science and Technology 33(4): 469-476.

EI Raey. 2010. Impact of sea level rise on the Arab region. Monograph for Regional Center for Disaster Risk Reduction, Arab Academy of Science, Technology and Maritime Transport. New York: Arab Climate Change Initiative, United Nations Development Programme. www.arabclimateinitiative.org/Countries/egypt/ElRaey_Impact_of_Sea_Level_Rise_on_the_Arab_Region. pdf

Gornitz, V.\& Kanciruk, P. 1989. Assessment of global coastal hazards from sea level rise (No. CONF8907104-1). Oak Ridge National Lab., TN (USA).

Gornitz, V. 1991. Global coastal hazards from future sea level rise. Palaeogeography, Palaeoclimatology. Palaeoecology 89: 379-398.

Gornitz, V., White, T. W.\& Cushman, R. M. 1991. Vulnerability of the US to future sea level rise (No. CONF-910780-1). Oak Ridge National Lab., TN (USA).

Hassan, A. \& Hassaan, M. A. 2020. Potential impact of sea level rise on the geomorphology of Kuwait state coastline. Arabian Journal of Geosciences 13:1139. https://doi.org/10.1007/s12517-020-06084-1.

Hereher, M. E. 2016. Vulnerability assessment of the Saudi Arabian Red Sea coast to climate change. Environmental Earth Sciences75(1): 1-13. http://www.coastalwiki.org/wiki/Setback_area 
IPCC. 2014. Climate change 2014: impacts, adaptation, and vulnerability. Cambridge University Press, New York, New York, USA.

Kantamaneni, K., Sudha Rani, N. N. V., Rice, L., Sur, K., Thayaparan, M., Kulatunga, U., Rege, R., Yenneti, K., \& Campos, L. C. 2019. A Systematic Review of Coastal Vulnerability Assessment Studies along Andhra Pradesh, India: A Critical Evaluation of Data Gathering, Risk Levels and Mitigation Strategies. Water 2019, 11, 393: 22 pages. doi:10.3390/w11020393

Kumar, A. A. \& Kunte, P. D. 2012. Coastal vulnerability assessment for Chennai, east coast of India using geospatial techniques. Natural Hazards64(1): 853-872.

Özyurt, G. \& Ergin, A. 2010. Improving coastal vulnerability assessments to sea-level rise: a new indicatorbased methodology for decision makers. Journal of Coastal Research 26, 265-273.

Rangel-Buitrago, N., Neal, W. J., Bonetti, J., Anfuso, G., \& de Jonge, V. N. 2020. Vulnerability assessments as a tool for the coastal and marine hazards management: An overview. Ocean and Coastal Management. $189,105134$.

Sanò, M., Jiménez, J. A., Medina, R., Stanica, A., Sanchez-Arcilla, A., \& Trumbic, I. 2011. The role of coastal setbacks in the context of coastal erosion and climate change. Ocean and Coastal Management $\mathbf{5 4}$ 943-950.

Shaw, J., Taylor, R. B., Forbes, D. L., Ruz, M. H. \& Solomon, S. 1998. Sensitivity of the coasts of Canada to sea level rise (p. 114). Ottawa: Geological Survey of Canada.

Shah, M. A., Renaud, F. G., Anderson, C. C., Wild, A., Domeneghetti, A., Polderman, A., Votsis, A., Pulvirenti, B., Basu, B., Thomson, C., Panga, D., Pouta, E., Toth, E., Pilla, F., Sahani, J., Ommer, J., El Zohbi, J., Munro, K., Stefanopoulou, M., Loupis, M., Pangas, N., Kumar, P., Debele, S., Preuschmann, S., \& Zixuan, W. 2020. A review of hydro-meteorological hazard, vulnerability, and risk assessment frameworks and indicators in the context of nature-based solutions. International Journal of Disaster Risk Reduction, Volume 50, November 2020, 101728. https://doi.org/10.1016/j.ijdrr.2020.101728.

Simpson, M. C., Mercer Clarke, C. S. L., Clarke, J. D., Scott, D., \& Clarke, A. J. 2012. Coastal Setbacks in Latin America and the Caribbean - A Study of Emerging Issues and Trends that Inform Guidelines for Coastal Planning and Development. Inter-American Development Bank VPS/ESG TECHNICAL NOTE No. IDB - TN -476.175 pages.

Tano, R. A., Aman, A., Toualy, E., Kouadio, Y. K., Xavier, B. B. D.F. \& Addo, K. A. 2018. Development of an integrated coastal vulnerability index for the Ivorian Coast in West Africa. Journal of Environmental Protection 9(11): 1171-1184.

Thieler, E. R.\& Hammar-Klose, E. S. 2000. National assessment of coastal vulnerability to sea-level rise; preliminary results for the US Pacific Coast (No. 2000-178).

Toimil, A., Losada, I. J., Nicholls, R. J., Dalrymple, R. A. \& Marcel, J. F. S. 2020. Addressing the challenges of climate change risks and adaptation in coastal areas: A review. Coastal Engineering 156, 103611.

Wahab, A. K. A. 2017. Coastal Vulnerability Index based on Sea-Level Rise. Session Keynote, $30^{\text {th }}$ National Geoscience conference and Exhibition, Kuala Lampur, 9-10 October 2017. 
Yin, J., Yin, Z., Wang, J. \& Xu, S. 2012. National assessment of coastal vulnerability to sea-level rise for the Chinese coast. Journal of Coastal Conservation16(1): 123-133.

Zanetti, V. B., Junior, W. C. de S. \& De Freitas, D. M. 2016. A Climate Change Vulnerability Index and Case Study in a Brazilian Coastal City. Sustainability8(811): 12 pages. 